\title{
Immediate angioplasty after thrombolysis: a systematic review
}

\author{
Warren J. Cantor, Fabrice Brunet, Carolyn P. Ziegler, Alex Kiss, Laurie J. Morrison
}

\section{ABSTRACT}

Background: The role of immediate transfer for percutaneous coronary intervention $(\mathrm{PCl})$ after thrombolysis for STsegment elevation myocardial infarction remains controversial. We performed a systematic review of the related literature to determine whether thrombolysis followed by transfer for immediate or early $\mathrm{PCl}$ is safe, feasible and superior to conservative management.

Methods: A systematic literature search of MEDLINE, EMBASE, the Cochrane Database for Systematic Reviews and Cochrane Central Register of Controlled Trials, and the American Heart Association EndNote 7 Master Library databases, was performed to 2004 for relevant published studies. The level of evidence and the quality of the study design and methods were rated by 2 reviewers according to a standardized classification. A quantitative meta-analysis was performed to assess the effect at 6-12 months on mortality of immediate or early $\mathrm{PCl}$ after thrombolysis.

Results: We found 13 articles that were supportive of immediate or early $\mathrm{PCl}$ after thrombolysis and 16 that were neutral or provided evidence opposing it. The largest randomized trials and meta-analyses showed no benefit of routine $\mathrm{PCI}$ immediately or shortly after thrombolysis. The studies that were supportive were generally more recent and more frequently involved coronary stents. One large trial supported early $\mathrm{PCl}$ after thrombolysis for patients with myocardial infarction complicated by cardiogenic shock. Overall, the difference in mortality rates between the invasive strategy and conservative care was nonsignificant. The 3 stent-era trials showed a significantly lower mortality among patients randomly assigned to the invasive strategy ( $5.8 \%$ v. $10.0 \%$, odds ratio $0.55,95 \%$ confidence interval $0.32-0.92$ ). Analysis of variance found a significant difference in treatment effect between stent-era and pre-stent-era trials.

Interpretation: At present, there is inadequate evidence to recommend routine transfer of patients for immediate or early $\mathrm{PCl}$ after successful thrombolysis. Results of recent trials using contemporary $\mathrm{PCl}$ techniques, including coronary stents, appear more favourable but need to be confirmed in large randomized trials, which are currently in progress. Transfer for immediate $\mathrm{PCl}$ is recommended for patients with cardiogenic shock, hemodynamic instability or persistent ischemic symptoms after thrombolysis.

CMAJ 2005;I73(I2):I473-8I
A lthough different strategies involving thrombolysis and angioplasty to treat ST-segment elevation myocardial infarction (STEMI) have been evaluated, until now there has been no precise assessment of immediate versus early percutaneous coronary intervention (PCI) after the administration of thrombolytic therapy in the treatment of STEMI. The timing of PCI after thrombolysis can be classified as immediate (as soon as possible after thrombolysis), early (within 24 hours after thrombolysis), rescue (performed only for failed thrombolysis) or deferred (more than 24 hours after thrombolysis). ${ }^{1}$ Immediate PCI after thrombolysis is often referred to as facilitated PCI.

The 2004 guidelines from the American College of Cardiology (ACC) and the American Heart Association (AHA) for treating STEMI recommend PCI immediately after thrombolysis: "Facilitated PCI, Class IIb [paragraph] I. Facilitated PCI might be performed as a reperfusion strategy in higher-risk patients when PCI is not immediately available and bleeding risk is low (Level of Evidence: B)" (p. 603) ${ }^{2}$ and "Percutaneous Coronary Intervention After Fibrinolysis, Class $I$ [paragraph] 3. In patients whose anatomy is suitable, PCI should be performed for cardiogenic shock or hemodynamic instability ... (Level of Evidence: B)" (p. 604). ${ }^{2}$

The systematic review summarized herein was undertaken, presented and debated as part of the International Liaison Committee on Resuscitation (ILCOR) evidence evaluation process. This process culminated in the 2005 International Consensus Conference on Cardiopulmonary Resuscitation and Emergency Cardiovascular Care Science with Treatment Recommendations, hosted by the AHA in Dallas, Jan. 23-30, 2005. As part of this process, international consensus documents have been posted on the Internet (available at www .c2005.org) and a summary ${ }^{3}$ was published.

The objective of this systematic overview was to determine whether a strategy of thrombolysis, administered in either a prehospital setting or a community hospital emergency department and followed by transfer for immediate or early PCI is safe, feasible and more effective than delayed PCI in the management of STEMI.

\section{Methods}

The following electronic databases were searched to 2004: Ovid's MEDLINE, MEDLINE In-Process \& Other Non-Indexed Citations, and EMBASE; the Cochrane Database for Systematic Reviews and Cochrane Central Register of Controlled Tri- 
als; and AHA's EndNote 7 Master Library. Complex search strategies were formulated using medical subject headings and text words to retrieve records that combined terms related to myocardial infarction, fibrinolytic therapy and angioplasty. The data set was refined by searching for articles in which the terms facilitated, immediate, early, adjunct, or combined occurred within 2-4 words of angioplasty, percutaneous coronary intervention, PCI, percutaneous transluminal angioplasty or PTCA. In addition, reference lists of articles were hand-searched for other relevant papers. Detailed steps of the electronic database search process are outlined in Appendix I (available at www.cmaj.ca/cgi/content/full/I73/I2 /I473/DCI).

Excluded were animal studies, studies published in abstract form only, articles not yet accepted for publication, investigations in which PCI was performed more than 24 hours after thrombolysis, studies in which only intracoronary thrombolysis was used, and trials with fewer than 30 subjects and no control group. Because most articles before 1985 focused on intracoronary thrombolysis, the literature search was initially limited to the year 1985 and onward. Abstracts from reports published from 1979 through 1984 found by means of MEDLINE ( 9 articles), Ovid MEDLINE In-Process \& Other Non-Indexed Citations (9) and EMBASE (3) were later reviewed to confirm this assumption.

The electronic databases were searched by an information specialist (C.P.Z.). After databases were combined and duplicate references were deleted, the search had generated 807 references. Titles and abstracts of each reference were then independently reviewed by 2 physicians (W.J.C. and F.B.); the report was omitted if any of the exclusion criteria listed above were met. If the eligibility of a reference remained in doubt after consideration of the abstract, the published article was examined. The reference lists of review articles were also searched for additional references.

The level of evidence for each article was graded from I (the highest level of evidence, such as a large, randomized trial) to 7 (the lowest level, e.g., rational conjecture or com-

Box 1: Definitions of levels of evidence, according to the American Heart Association's ILCOR evaluation process

1 Randomized clinical trials or meta-analyses of multiple clinical trials with substantial treatment effects

2 Randomized clinical trials with smaller or less significant treatment effects

3 Prospective controlled, nonrandomized, cohort studies

4 Historic nonrandomized, cohort or case-control studies

5 Case series: patients compiled in serial fashion, lacking a control group

6 Animal studies or mechanical model studies

7 Extrapolations from existing data collected for other purposes, theoretical analyses

8 Rational conjecture (common sense); common practices that were accepted before evidence-based guidelines

Note: ILCOR = the International Liaison Committee on Resuscitation.
Box 2: Definitions of ratings of study design and methods, according to the American Heart Association's ILCOR evaluation process

Excellent (both of the following) or good (one of):

- Design - highly appropriate sample or model; randomized; proper choice of controls

- Methods - outstanding accuracy, precision and data collection in its class of study

Fair - one of:

- Design - adequate design, but possibly biased

- Methods - adequate under the circumstances

Poor - one of:

- Design - small or clearly biased population or model

- Methods - weakly defensible in its class; limited data or measures

Unsatisfactory - one of:

- Design - anecdotal, no controls, off target end-points

- Methods - not defensible in its class; insufficient data or measures

Note: ILCOR = the International Liaison Committee on Resuscitation.

mon sense; Box I); and the design and methods, as excellent, good, fair, poor or unsatisfactory, both according to the AHA's ILCOR classification (Box 2).

A quantitative meta-analysis was performed of only those randomized trials that compared routine PCI performed within 24 hours after thrombolysis with more conservative management. The end points used for the meta-analysis included death and a composite of death and reinfarction by 12 months (or, if that information was unavailable, by 6 months) after the procedure. The statistical analysis was performed and the Forest plots were generated using Comprehensive Meta Analysis software (version I.0.23, Biostat, Englewood, NJ). The inverse-variance computational model (which uses logs of the odds ratios [ORs]) was used in a fixed-effects model. The type of trial was classified as "pre-stent era" if coronary stents were used in fewer than $50 \%$ of PCI cases, or as "stent era" otherwise. Era trial type was used as a moderator variable, and the ANOVA (analysis of variance) option was used to determine whether differences in treatment effect between the 2 era types were significant $(p<0.05)$. The $\mathrm{Q}$ statistic was calculated to assess if significant heterogeneity was present between trials.

\section{Results}

The electronic database search identified 807 articles, of which only 37 reported on trials that met the inclusion criteria (Fig. I)..$^{4-40}$ Eight articles ${ }^{10-17}$ reported on studies that were assigned ILCOR design and methods scores of poor quality, and were not included in the 2 summary tables.

Of the 29 articles remaining, the findings of $I_{3}$ studies were supportive of immediate or early PCI after thrombolysis (Table I); those of 7 were neutral; and the results from 9 provided evidence opposing immediate or early PCI with increased mortality or requirements for transfusion or coronary 
artery bypass grafting in the treatment group (Table 2; more detailed versions of these 2 tables can be accessed through the Internet, by going to www.cmaj.ca/cgi/content/full/173 /I2/I473/DC2).

\section{Studies showing benefit by qualitative assessment}

Evidence from 6 relatively small trials (level I evidence for 2 studies, level 2 for 4 studies) showed a benefit for immediate or early PCI after thrombolysis. ${ }^{18-23}$ Of these trials, 3 used coronary stents for the majority of patients undergoing PCI. ${ }^{18,20,21}$

A strategy of thrombolysis combined with transfer for immediate or early PCI was supported by 3 good-quality but relatively small randomized trials (levels of evidence $\mathrm{I}^{19,20}$ and $2^{18}$ ) and 3 small randomized trials $\mathrm{s}^{21-23}$ of fair quality (level 2). Other supportive randomized trials had been presented at scientific meetings but not yet published (CAPITAL AMI, ${ }^{41,42}$ GRACIA-2). Timing of PCI after thrombolysis, inclusion of patients requiring transfer for PCI, use of coronary stents and control-group interventions differed considerably among these trials. The efficacy of this strategy is also supported by 2 post-hoc nonrandomized comparisons (levels $3^{24}$ and $7^{25}$ ); its feasibility, by 2 level-7 trials ${ }^{14,26}$ in which fibrinolysis or placebo was administered before immediate cardiac catheterization and PCI as necessary.

\section{Studies showing neutral effect or no benefit by qualitative assessment}

Evidence from 5 randomized trials (level I evidence for 3 studies, and levels 2 and 7 for one study apiece) and 3 level-I meta-analyses showed no benefit of immediate or early PCI after thrombolysis. Most of these trials did not involve transfer for PCI and did not use contemporary pharmacotherapy and contemporary angioplasty techniques.

A strategy of thrombolysis combined with transfer for immediate or early PCI was not supported by 3 level-I randomized trials, ${ }^{27-29}$ one level- $2^{30}$ and one level-7 trial, ${ }^{31}$ and several nonrandomized studies or secondary analyses of trials. Several level-I meta-analyses ${ }^{32-34}$ also showed no benefit of immediate or early PCI. However, all but one of these trials were carried out before the era of coronary stenting, and none utilized modern pharmacological therapies or contemporary PCI techniques. The most recent study ${ }^{30}$ was fairly small (Ioo patients per treatment group) and showed a benefit of immediate PCI with prolonged follow-up. ${ }^{18}$

\section{Quantitative meta-analysis findings}

The results of the quantitative meta-analysis are shown in Fig. 2 and Fig. 3. The 37 articles identified in the search strategy included I8 randomized controlled trials. Of these, 5 trials compared immediate or early PCI after thrombolysis with primary PCI; 4 trials evaluated PCI for failed thrombolysis or cardiogenic shock; and one trial had no long-term outcomes reported. The 8 remaining trials ( 5 pre-stent-era and 3 stentera trials) were included in the quantitative meta-analysis. Outcomes were reported at 12 months for all but one trial, SIAM- $3,{ }^{21}$ which only reported outcomes up to 6 months.

Overall, there were no statistically significant differences in mortality (OR 0.89 , 95\% confidence interval [CI] 0.67I.I9; Fig. 2) or in a composite of death and reinfarction (OR o.8I, 95\% CI o.65-I.oI; Fig. 3) within I2 months (6 mo, for SIAM $-3^{21}$ ) between the "invasive" strategy (immediate or early

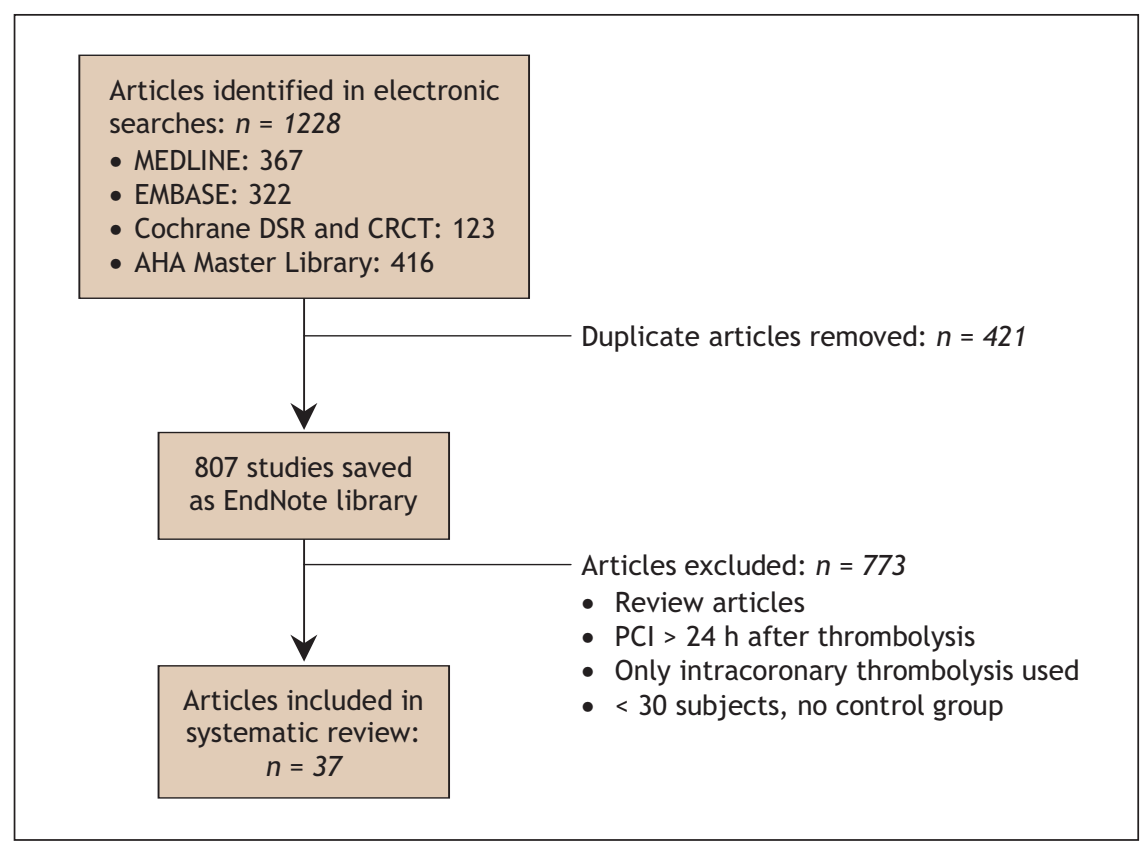

Fig. 1: Literature-search flow chart. DSR = Database for Systematic Reviews, CRCT = Cochrane Central Register of Controlled Trials, AHA = American Heart Association, $\mathrm{PCl}=$ percutaneous coronary intervention. 
PCI after thrombolysis) and the "conservative," noninvasive strategy. Similarly, among the 5 pre-stent-era trials there were no significant differences in mortality or in combined death and reinfarction within 12 months. However, in the 3 stent-era trials, there were significantly lower rates of death (OR 0.55, 95\% CI 0.32-0.92; Fig. 2) and death or reinfarction (OR 0.59, 95\% CI 0.39-0.89; Fig. 3) within I2 months for patients randomly assigned to the invasive strategy.

There was no evidence of significant heterogeneity among the 8 trials overall $(\mathrm{Q}=9.99, p=0.19$ for death; $\mathrm{Q}=9.6 \mathrm{I}, p=$ $0.2 \mathrm{I}$ for combined death and reinfarction, each within I2 $\mathrm{mo})$, among the 5 pre-stent-era trials $(\mathrm{Q}=4.86, p=0.30$ for death; $\mathrm{Q}=3.65, p=0.45$ for death/reinfarction) or among the 3 stent-era trials $(\mathrm{Q}=0.29, p=0.86$ for death; $\mathrm{Q}=0.2 \mathrm{I}, p=$ 0.90 for death/reinfarction, each within $12 \mathrm{mo}$ ). The ANOVA results indicated a significant difference in treatment effects between the stent-era and pre-stent-era trial groups $(p=0.03$ for death, $p=0.0 \mathrm{I}$ for death/reinfarction within 6-I2 mo). Funnel plots for death and for a composite of death and reinfarction (which are available online as Appendixes 2 and 3, respectively, at www.cmaj.ca/cgi/content/full/173/I2/I473 /DCI) within 6-I2 months did not reveal any obvious asymmetry, which suggests that publication bias did not influence the findings of the meta-analysis.

\section{Studies of PCI treatment for cardiogenic shock or failed thrombolysis}

In the SHOCK randomized trial (level I), ${ }^{35,43}$ early revascularization in patients with myocardial infarction complicated by

Table 1: Studies that found an advantage for early percutaneous coronary intervention after thrombolysis versus delayed intervention

\begin{tabular}{|c|c|c|c|c|}
\hline $\begin{array}{l}\text { First author, year, } \\
\text { no. of participants }\end{array}$ & Intervention & Comparison group & $\begin{array}{l}\text { ILCOR } \\
\text { LoE }\end{array}$ & Main result \\
\hline $\begin{array}{l}\text { Califf } 191991 \\
n=575\end{array}$ & $\begin{array}{l}\text { Immediate cath } \\
\pm \text { rescue } \mathrm{PCI} \text { for } \\
\text { failed thrombolysis }\end{array}$ & $\begin{array}{l}\text { Cath at } 5-10 \mathrm{~d} \\
\text { after thrombolysis }\end{array}$ & 1 & $\begin{array}{l}\text { Fewer adverse outcomes ( } 33 \% \text { v. } 45 \% ; p=0.004) \text { and } \\
\text { a trend toward higher patency with immediate cath }\end{array}$ \\
\hline $\begin{array}{l}\text { Hochman }^{35} 1999 \\
n=302\end{array}$ & $\begin{array}{l}\text { Emergency } \mathrm{PCl} / \mathrm{CABG} \\
\text { for cardiogenic shock }\end{array}$ & $\begin{array}{l}\text { Conservative non- } \\
\text { interventional strategy }\end{array}$ & 1 & $\begin{array}{l}\text { Survival improved at } 6 \text { mo with emergency } \\
\text { revascularization (OR } 0.80,95 \% \mathrm{Cl} 0.54-0.98)\end{array}$ \\
\hline $\begin{array}{l}\text { Bednar }^{18} 2003 \\
n=300\end{array}$ & $\begin{array}{l}\text { Group B: } \\
\text { thrombolysis during } \\
\text { transfer for cath, } \\
\mathrm{PCl} \text { (stent) }\end{array}$ & $\begin{array}{l}\text { Group A: thrombolysis } \\
\text { without transfer } \\
\text { Group C: transfer for } \\
\text { primary PCl }\end{array}$ & 2 & $\begin{array}{l}\text { No difference in overall mortality; lower cardiac mortality } \\
\text { for early presenters (within } 2 \text { h): group A } 18 \% \text {, B 3\%, C } 8 \% \\
(p<0.05)\end{array}$ \\
\hline $\begin{array}{l}\text { Ellis }^{37} 1994 \\
n=151\end{array}$ & $\begin{array}{l}\text { Rescue } \mathrm{PCl} \text { after } \\
\text { failed thrombolysis }\end{array}$ & $\begin{array}{l}\text { Conservative non- } \\
\text { interventional strategy }\end{array}$ & 2 & $\begin{array}{l}\text { Trend toward lower rates of death/severe CHF }(6 \% \text { v. } 17 \% \text {; } \\
p=0.05) \text { and improvement in exercise LVEF with rescue PCI }\end{array}$ \\
\hline $\begin{array}{l}\text { Vermeer }^{23} 1999 \\
n=224\end{array}$ & $\begin{array}{l}\text { tPA followed } \\
\text { by transfer for } \\
\text { immediate cath, } \\
\text { rescue } \mathrm{PCl} \text { if needed }\end{array}$ & $\begin{array}{l}\text { tPA alone, or transfer } \\
\text { for primary } \mathrm{PCl}\end{array}$ & 2 & $\begin{array}{l}\text { No complications during transport; no significant } \\
\text { differences in outcomes }\end{array}$ \\
\hline $\begin{array}{l}\text { Herrmann }{ }^{24} 2000 \\
n=323\end{array}$ & $\begin{array}{l}\mathrm{PCl} \text { (stent) } 90 \mathrm{~min} \\
\text { after reteplase } \\
\text { and/or abciximab }\end{array}$ & $\begin{array}{l}\text { Conservative non- } \\
\text { interventional strategy }\end{array}$ & 3 & $\begin{array}{l}\text { Less reinfarction }(1.2 \% \text { v. } 4.9 \% ; p=0.03) \text { and need for } \\
\text { urgent revascularization }(1.6 \% \text { v. } 9.3 \% ; p=0.001)\end{array}$ \\
\hline $\begin{array}{l}\text { Kurihara }{ }^{14} 2004 \\
n=39\end{array}$ & $\begin{array}{l}\text { Monteplase + } \\
\mathrm{PCl} \text { (stent) }\end{array}$ & Primary PCI (stent) & 7 & $\begin{array}{l}\text { Higher rate of patency pre-PCI with monteplase; } \\
\text { no difference in LVEF }\end{array}$ \\
\hline
\end{tabular}

Note: A more detailed version of this table is available on the Web (at www.cmaj.ca/cgi/content/full/173/12/1473/DC1).

$\mathrm{ILCOR}=$ International Liaison Committee on Resuscitation, $\mathrm{LoE}=$ level of evidence, cath $=$ cardiac catheterization, $\mathrm{PCI}=$ percutaneous coronary intervention, $\mathrm{CABG}=$ coronary artery bypass graft surgery, $\mathrm{OR}=$ odds ratio, $\mathrm{Cl}=$ confidence interval, $\mathrm{tPA}=$ tissue plasminogen activator, $\mathrm{LVEF}=\mathrm{left}-\mathrm{ventricular}$ ejection fraction, $\mathrm{CHF}=$ congestive heart failure. 
cardiogenic shock (within 36 hours after infarction and within 12 hours after onset of shock) was shown to improve mortality at 6 months and I year compared with initial medical stabilization. About half of the patients in that trial had received thrombolysis. Among those randomly assigned to early revascularization, PCI accounted for $64 \%$ of initial revascularization procedures; bypass surgery, for $36 \%$. Median time from myocardial infarction to randomization was II hours; from randomization to PCI, o.9 hours. These findings were further supported by retrospective analysis in the GUSTO-I trial $^{36}$ (level 7), which found that early angiography (within 24 hours of onset of cardiogenic shock) and revascularization was associated with lower mortality at 30 days.

The published evidence to support rescue PCI for patients who do not reperfuse after thrombolysis is more limited. One small randomized trial ${ }^{37}$ (level 2) showed an improvement in exercise left-ventricular ejection fraction and a reduction in combined death and congestive heart failure with

Table 2: Studies that did not show an advantage for early coronary intervention after thrombolysis versus delayed intervention

\begin{tabular}{|c|c|c|c|c|}
\hline $\begin{array}{l}\text { First author, year, } \\
\text { no. of participants }\end{array}$ & Intervention & Comparison group & $\begin{array}{l}\text { ILCOR } \\
\text { LoE }\end{array}$ & Main result \\
\hline $\begin{array}{l}\text { TIMI Research } 28 \\
1988, n=389\end{array}$ & $\begin{array}{l}\text { Immediate } \mathrm{PCl} \\
\text { after tPA }\end{array}$ & $\begin{array}{l}\text { Cath/PCl at } 18-48 \mathrm{~h} \\
\text { after tPA }\end{array}$ & 1 & $\begin{array}{l}\text { Increased transfusion and CABG (16\% v. 8\%; } p=0.01) \text {; } \\
\text { no difference in LVEF }\end{array}$ \\
\hline $\begin{array}{l}\text { Rogers }^{6} 1990 \\
n=586\end{array}$ & $\begin{array}{l}\text { Immediate } \mathrm{PCl} \\
\text { after tPA }\end{array}$ & $\begin{array}{l}\mathrm{PCl} \text { at } 18-48 \mathrm{~h} \text { after } \\
\mathrm{tPA} \text {, or ischemia- } \\
\text { guided } \mathrm{PCl}\end{array}$ & 1 & $\begin{array}{l}\text { No improvement in mortality, increased transfusion or } \\
\text { CABG; no difference in LVEF }\end{array}$ \\
\hline $\begin{array}{l}\text { Simoons }{ }^{27} 1988 \\
n=367\end{array}$ & $\begin{array}{l}\text { Immediate } \mathrm{PCl} \\
\text { after tPA }\end{array}$ & $\begin{array}{l}\text { Conservative non- } \\
\text { interventional strategy }\end{array}$ & $1-$ & $\begin{array}{l}\text { Trend toward higher mortality at } 14 \mathrm{~d}(7 \% \text { v. } 3 \% ; p=0.08) \text {; } \\
\text { no difference in infarct size or LVEF }\end{array}$ \\
\hline $\begin{array}{l}\text { Michels } 331995 \\
n=2243\end{array}$ & $\begin{array}{l}\text { Immediate } \mathrm{PCl} \\
\text { after thrombolysis }\end{array}$ & $\begin{array}{l}\text { Delayed or no } \mathrm{PCl} \\
\text { after thrombolysis }\end{array}$ & 1 & $\begin{array}{l}\text { No difference in death/reinfarction at } 6 \mathrm{wk} \text { and } 1 \mathrm{yr} \\
(\mathrm{OR} 1.38,95 \% \mathrm{Cl} 0.81-2.34)\end{array}$ \\
\hline $\begin{array}{l}\text { Topol }^{29} 1987 \\
n=197\end{array}$ & $\begin{array}{l}\text { Transfer for cath } \\
90 \text { min after } \mathrm{PAA} \text {, } \\
\text { immediate } \mathrm{PCl}\end{array}$ & $\begin{array}{l}\text { Transfer for cath } \\
90 \text { min after tPA, } \\
\text { elective } \mathrm{PCl} \text { at } 7-10 \mathrm{~d}\end{array}$ & 1 & $\begin{array}{l}\text { No difference in death, reocclusion; no difference in } \\
\text { regional left-ventricular wall motion }\end{array}$ \\
\hline $\begin{array}{l}\text { Jovell }{ }^{32} 1993 \\
n=5882\end{array}$ & $\begin{array}{l}\text { Early } \mathrm{PCl} \text { after } \\
\text { thrombolysis }\end{array}$ & $\begin{array}{l}\text { Conservative non- } \\
\text { interventional strategy }\end{array}$ & 11 & No difference in mortality, reinfarction \\
\hline $\begin{array}{l}\text { Topol }^{34} 1988 \\
n=1142\end{array}$ & $\begin{array}{l}\text { Immediate } \mathrm{PCl} \\
\text { after thrombolysis }\end{array}$ & $\begin{array}{l}\text { See Topol }{ }^{87} \\
\text { Simmoons } \\
\text { TIMI and } \\
\text { Tesearch }\end{array}$ & 1 & $\begin{array}{l}\text { No improvement in mortality or LVEF; increased rates of } \\
\text { transfusion and CABG }\end{array}$ \\
\hline $\begin{array}{l}\text { Arnold } 1991 \\
n=291\end{array}$ & $\begin{array}{l}\text { Immediate } \mathrm{PCl} \\
\text { after tPA }\end{array}$ & $\begin{array}{l}\text { Conservative non- } \\
\text { interventional strategy }\end{array}$ & 2 & No difference in regional left-ventricular wall motion \\
\hline $\begin{array}{l}\text { Arnold }^{8} 1992 \\
n=367\end{array}$ & $\begin{array}{l}\text { Immediate PCI } \\
\text { after tPA }\end{array}$ & $\begin{array}{l}\text { Conservative non- } \\
\text { interventional strategy }\end{array}$ & 2 & $\begin{array}{l}\text { Trend toward increased mortality at } 1 \mathrm{yr}(9 \% \text { v. } 5 \% \text {; } \\
p=0.16)\end{array}$ \\
\hline $\begin{array}{l}\text { De Bono } 41988 \\
n=367\end{array}$ & $\begin{array}{l}\text { Immediate } \mathrm{PCl} \\
\text { after tPA }\end{array}$ & $\begin{array}{l}\text { Conservative non- } \\
\text { interventional strategy }\end{array}$ & 2 & $\begin{array}{l}\text { Trend toward increased mortality at } 3 \mathrm{mo} \text {; no difference } \\
\text { in LVEF, infarct size or coronary patency }\end{array}$ \\
\hline \multirow[t]{2}{*}{$\begin{array}{l}\text { Widimsky }{ }^{30} 2000 \\
n=300\end{array}$} & \multirow{2}{*}{$\begin{array}{l}\text { Group B: thrombolysis } \\
\text { during transfer for } \\
\text { cath, } \mathrm{PCl} \text { (stent) }\end{array}$} & $\begin{array}{l}\text { Group A: thrombolysis } \\
\text { without transfer }\end{array}$ & \multirow[t]{2}{*}{2} & \multirow[t]{2}{*}{$\begin{array}{l}\text { Rates of death, reinfarction and stroke similar to those of } \\
\text { group A, higher than those of group C }\end{array}$} \\
\hline & & $\begin{array}{l}\text { Group C: transfer for } \\
\text { primary } \mathrm{PCl}\end{array}$ & & \\
\hline $\begin{array}{l}\text { Erbel }^{5} 1989 \\
n=206\end{array}$ & $\begin{array}{l}\mathrm{PCl} \text { after intravenous } \\
\text { and subcutaneous } \\
\text { streptokinase }\end{array}$ & $\begin{array}{l}\text { Conservative non- } \\
\text { interventional strategy }\end{array}$ & 3 & $\begin{array}{l}\text { No difference in mortality at } 3 \mathrm{yr} \text {; no improvement in left- } \\
\text { ventricular function }\end{array}$ \\
\hline $\begin{array}{l}\text { Ellis } 1994 \\
n=108\end{array}$ & $\begin{array}{l}\text { Immediate } \mathrm{PCl} \text { after } \\
\text { thrombolysis with } \\
\text { TIMI-2 flow }\end{array}$ & $\begin{array}{l}\text { Conservative non- } \\
\text { interventional strategy }\end{array}$ & 7 & $\begin{array}{l}\text { No difference in death or CHF; slightly higher LVEF } \\
\text { improvement with early } \mathrm{PCI}\end{array}$ \\
\hline $\begin{array}{l}\text { O’Neill' } 1992 \\
n=122\end{array}$ & $\begin{array}{l}\text { Streptokinase followed } \\
\text { by immediate PCI }\end{array}$ & Primary $\mathrm{PCl}$ & 7 & $\begin{array}{l}\text { Higher rate of transfusion and emergency CABG }(10 \% \\
\text { v. } 1.6 \% ; p=0.03) \text {; no difference in LVEF or patency }\end{array}$ \\
\hline $\begin{array}{l}\text { Sutton }^{38} 2004 \\
n=307\end{array}$ & $\begin{array}{l}\text { Rescue } \mathrm{PCl} \text { after } \\
\text { failed thrombolysis }\end{array}$ & $\begin{array}{l}\text { Conservative non- } \\
\text { interventional strategy }\end{array}$ & 2 & $\begin{array}{l}\text { Higher rate of transfusion }(11 \% \text { v. } 1 \% ; p<0.001) \text { and stroke } \\
(5 \% \text { v. } 1 \% ; p=0.03) \text {; at } 30 \mathrm{~d} \text {, no difference in mortality or } \\
\text { regional wall motion }\end{array}$ \\
\hline $\begin{array}{l}\text { Kastrati }^{40} 2004 \\
n=253\end{array}$ & $\begin{array}{l}\text { Half-dose reteplase } \\
+ \text { abciximab followed } \\
\text { by transfer for } \\
\text { immediate } \mathrm{PCl}\end{array}$ & $\begin{array}{l}\text { Abciximab followed } \\
\text { by transfer for } \\
\text { immediate } \mathrm{PCl}\end{array}$ & 7 & $\begin{array}{l}\text { No difference in death, reinfarction or stroke; trend toward } \\
\text { increased bleeding with reteplase }(6 \% \mathrm{v} .2 \% ; p=0.16) \text {; } \\
\text { no difference in SPECT infarct size at } 5-10 \mathrm{~d}\end{array}$ \\
\hline
\end{tabular}

Note: A more detailed version of this table is available on the Web (at www.cmaj.ca/cgi/content/full/173/12/1473/DC1).

ILCOR = International Liaison Committee on Resuscitation, $\mathrm{LoE}=$ level of evidence, $\mathrm{PCI}=$ percutaneous coronary intervention, $\mathrm{tPA}=$ tissue plasminogen activator, $\mathrm{CABG}$ = coronary artery bypass graft surgery, LVEF = left-ventricular ejection fraction, LV = left-ventricular, CHF = congestive heart failure, SPECT = single-photon emission computed tomography. 
rescue PCI. A more recent level-2 trial ${ }^{38}$ showed a reduced requirement for subsequent revascularization with rescue PCI but an increased need for transfusion and no difference in 30-day mortality.

\section{Interpretation}

We conducted a systematic review of clinical trials examining the use of routine immediate transfer of patients with STEMI from community hospitals to cardiac catheterization centres for immediate or early PCI after thrombolysis. Our findings indicate that at present, there is inadequate evidence to recommend routine transfer of patients for immediate or early PCI after successful prehospital or inhospital thrombolysis and initial stabilization in community hospital emergency departments.

The potential benefits of routine immediate or early PCI after thrombolysis include prevention of reinfarction and recurrent ischemia, and reduction of infarct size in patients who fail to reperfuse after thrombolysis. Risks include bleeding, vascular complications, and cardiac arrhythmias or arrest during ambulance transportation. The cost-effectiveness of this strategy, including consideration of the need for additional cardiac catheterization laboratories, staffing, ambulances and paramedics, has not been studied.

Published findings are conflicting, and the related literature is difficult to interpret. Because the pharmacological management of STEMI and PCI techniques and adjunct pharmacotherapy have changed considerably (e.g., coronary stents, thienopyridines and glycoprotein [GP] IIb/IIIa inhibi- tors), it may be inappropriate to compare the large randomized trials conducted in the 1980 s with more recent studies. Whereas the older trials showed no benefit of immediate or early PCI after thrombolysis and trends toward increased rates of adverse events, this may have resulted from higher rates of reocclusion and reinfarction after initially successful PCI. ${ }^{4}$ Advances in percutaneous coronary intervention and adjuvant pharmacotherapy since that time have led to lower rates of reocclusion and reinfarction.

More recent observational studies and small randomized trials have been more supportive of immediate or early PCI after thrombolysis. ${ }^{21}$ Many recent studies have been presented in abstract form but were not yet published at the time this analysis was conducted (e.g., GRACIA-2, CAPITAL AMI ${ }^{41}$ ) and were therefore not included in this worksheet, as per the ILCOR guidelines. Our meta-analysis showed significantly lower rates of death and of death or reinfarction at 6 months $\mathrm{s}^{21}$ to I year with immediate or early PCI after thrombolysis compared with conservative care in the 3 published randomized trials involving coronary stents. Furthermore, differences in treatment effects between trials carried out in the pre-stent and stent eras were significant. Nevertheless, given the small number of trials, limited numbers of patients and differences in study design, these results should be viewed as hypothesisgenerating and require confirmation in large randomized trials using contemporary PCI techniques and pharmacotherapy. Such trials ${ }^{39,44,45}$ are in progress.

Another limitation of published studies is that most of the trials evaluating immediate or early PCI after thrombolysis have been carried out in centres with on-site angioplasty facil-

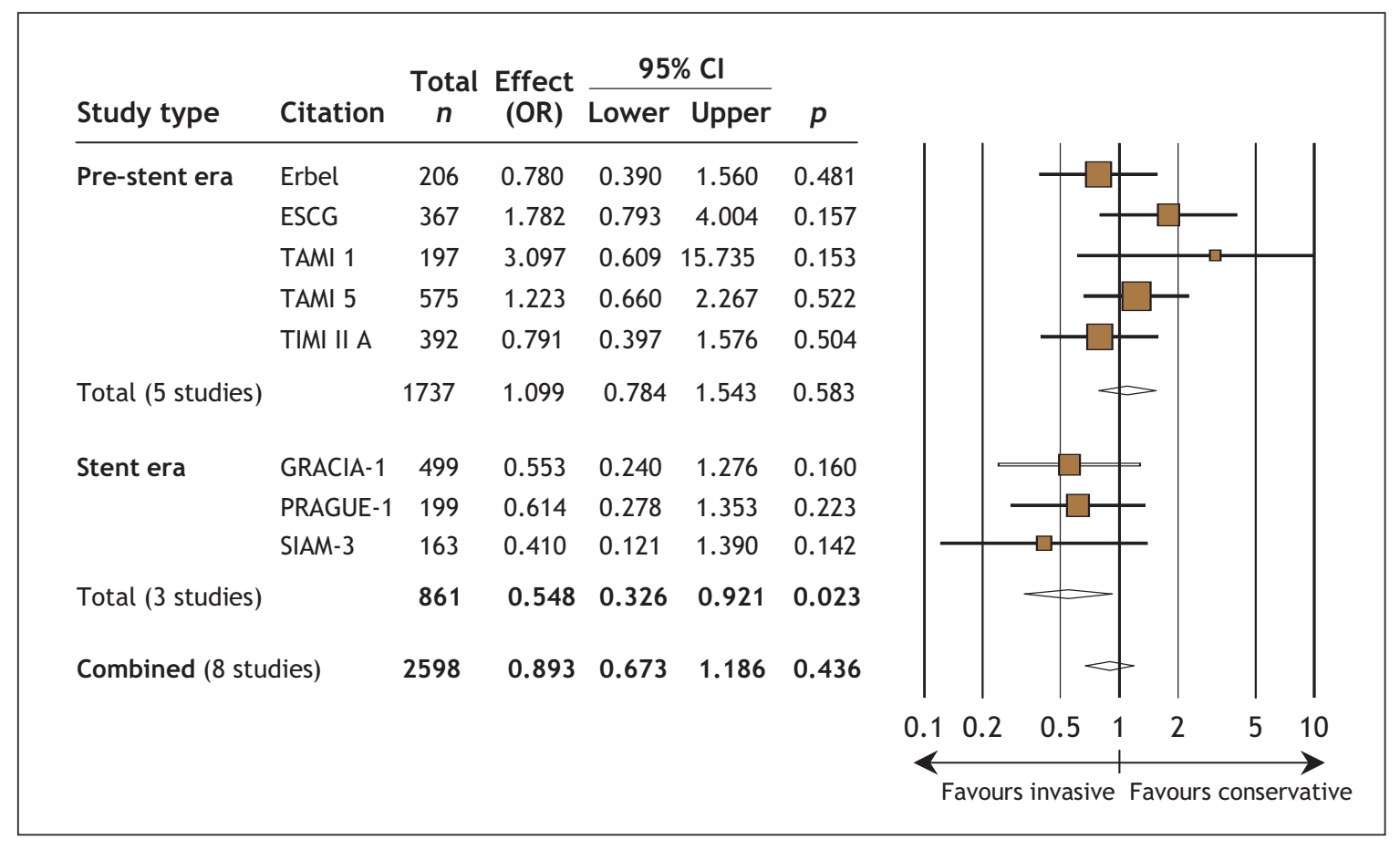

Fig. 2: Forest plot of odds ratios for death within 12 months ( 6 months, in the SIAM-3 trial). This plot shows a fixedmodel analysis; similar numbers from a random-model analysis are included in an online version of Fig. 2 (available at www.cmaj.ca/cgi/content/full/173/12/1473/DC3). 
ities, where patients did not require transfer to another institution for PCI. Nevertheless, several large series have documented the safety and feasibility of transferring patients to PCI centres after thrombolysis. ${ }^{16,23,30}$ Ongoing randomized trials are comparing the secondary transfer of patients for immediate or early PCI after thrombolysis with initial stabilization in community emergency departments or in prehospital settings. ${ }^{44,45}$

All of the studies included in this systematic overview used in-hospital administration of thrombolysis. The use of prehospital thrombolysis with initial stabilization in a community hospital followed by transfer for routine immediate or early PCI has not been studied. The comparison of prehospital thrombolysis to primary PCI is covered in a separate review by the ILCOR Acute Coronary Syndrome/Acute Myocardial Infarction Task Force.

To further complicate the interpretation of the existing literature, there is significant heterogeneity in the control groups among the studies included in our systematic review. Diagnostic coronary angiography for control-group patients was performed immediately in one trial, ${ }^{29}$ delayed ( $>24 \mathrm{~h}$ after thrombolysis) in several ${ }^{19,28}$ and performed only for recurrent ischemia in others. ${ }^{20,27}$ In some studies, patients in the control group routinely underwent delayed PCI, ${ }^{21,28}$ whereas in others, patients in the control groups were treated medically unless they had spontaneous or inducible ischemia. ${ }^{20,27}$ For studies in which all control-group patients underwent primary PCI, ${ }^{14,26,31,40}$ no inference could be made on the efficacy of immediate or early angioplasty after thrombolysis compared with delayed angioplasty, and only the safety and feasi- bility of this approach was evaluated. The symmetry seen in the funnel plots and the large number of published studies with neutral or opposing results suggest that publication bias was unlikely to have had a major impact on the findings of this systematic overview.

The evidence for early revascularization in patients with cardiogenic shock is clearer. The SHOCK trial ${ }^{35,43}$ demonstrated a significant mortality benefit with early coronary revascularization within $\mathrm{I} 2$ hours of shock onset. Among the patients who were randomly assigned to early revascularization, $64 \%$ underwent PCI and $36 \%$ underwent bypass surgery. Over $50 \%$ of the patients enrolled in this trial had received thrombolytic therapy. These findings were supported by a nonrandomized analysis from the first GUSTO trial. ${ }^{36}$ The 2004 ACC-AHA STEMI guidelines ${ }^{2}$ list emergent rescue angioplasty for patients with cardiogenic shock as a class I recommendation for patients younger than 75 years, and a class IIa recommendation for selected patients 75 years or older. A benefit of rescue PCI for patients who fail to reperfuse after thrombolysis was observed in one small randomized trial ${ }^{37}$ (level 2), which showed improvement in exercise left-ventricular ejection fraction and lower rates of death and congestive heart failure. In the MERLIN trial, ${ }^{38}$ rescue PCI reduced the need for subsequent revascularization but was associated with increased transfusions and had no effect on 30-day survival rates or left-ventricular function. More compelling evidence for a benefit from rescue PCI was documented in a recent trial (the REACT trial ${ }^{46}$ ) that resulted in a lower incidence of death, reinfarction, stroke and heart failure at 6 months compared with conservative management. Although

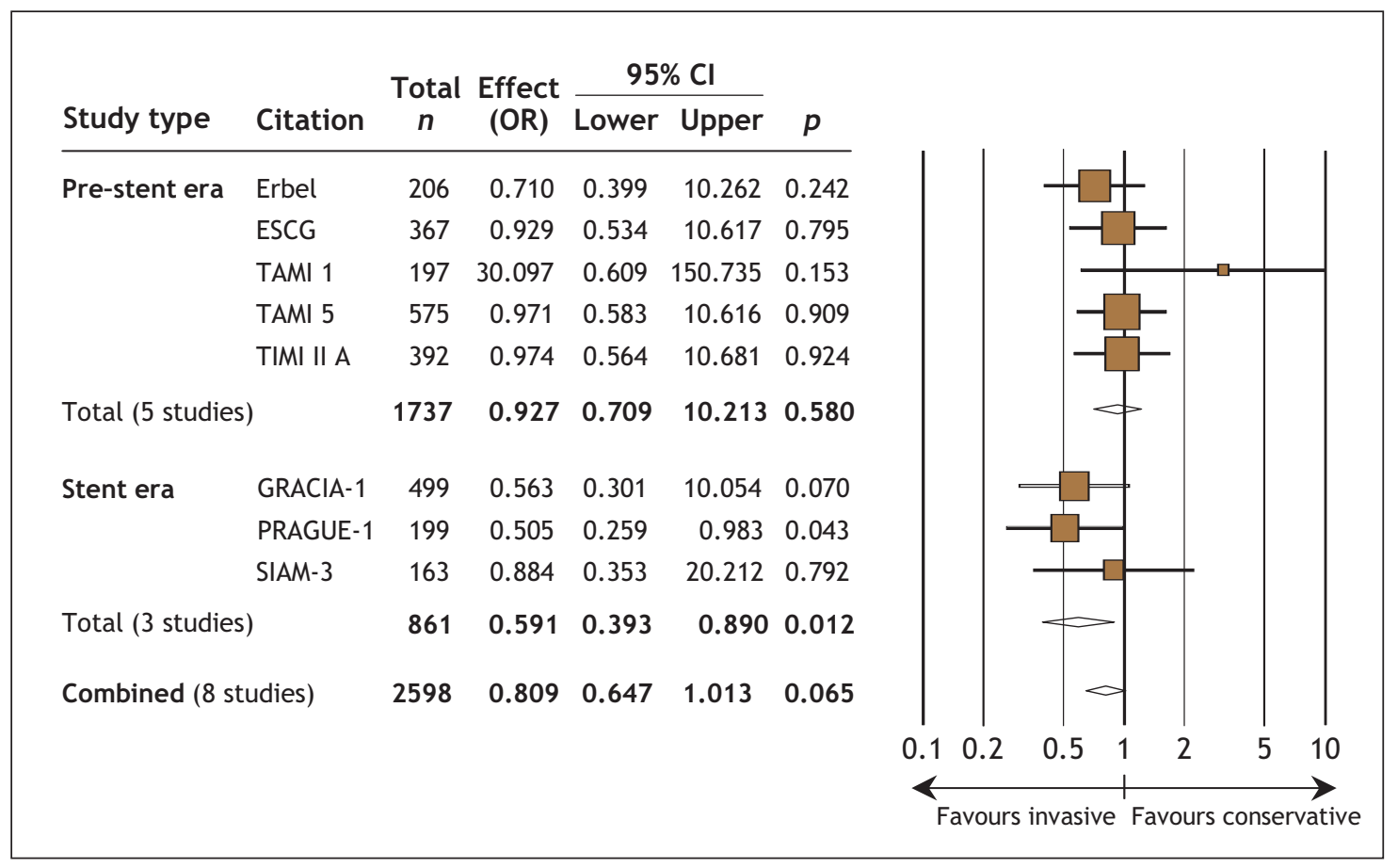

Fig. 3: Forest plot of odds ratios for combined death and myocardial reinfarction within 12 months ( 6 months, in the SIAM-3 trial). This plot shows a fixed-model analysis; similar numbers from a random-model analysis are included in an online version of Fig. 3 (available at www.cmaj.ca/cgi/content/full/173/12/1473/DC 3 ). 
there remains uncertainty about the role of routine transfer for immediate or early PCI after successful thrombolysis, transfer for immediate PCI is recommended for patients with cardiogenic shock, hemodynamic instability or persistent ischemic symptoms after thrombolysis.

Recommendations arising from the scientific evidence can be translated into guidelines for the management of STEMI in the emergency department. There are no indications for immediate transfer for PCI after successful thrombolysis. For patients with cardiogenic shock or failed thrombolysis, transfer should be arranged, with close monitoring of the patient. This approach requires developing a network of care with a tertiary care facility as well as an appropriate transport system. Recent studies showing a benefit from pharmaceutical agents (fibrinolytic agents or GP IIb/IIIa inhibitors) given en route to the catheterization laboratory to enhance the efficacy of PCI ("facilitated PCI") require confirmation in large, multicentre, randomized trials. This strategy remains investigational and cannot be currently recommended in emergency medicine practice.

\section{This article has been peer reviewed.}

From the Divisions of Cardiology (Cantor) and Critical Care Medicine (Brunet), St. Michael's Hospital, and the Department of Medicine, University of Toronto; Health Sciences Library, St. Michael's Hospital (Ziegler); the Department of Research Design and Biostatistics, Institute for Clinical and Evaluative Sciences (Kiss); and the Prehospital and Transport Medicine Research Program, Department of Emergency Services, Sunnybrook and Women's College Health Science Centre, and the Division of Emergency Medicine, Department of Medicine, University of Toronto, Institute for Clinical and Evaluative Sciences (Morrison), Toronto.

Competing interests: None declared for Fabrice Brunet, Carolyn Ziegler and Alex Kiss. Warren Cantor is the principal investigator of TRANSFER-AMI, a large randomized trial comparing immediate angioplasty with the conservative approach after thrombolysis, funded by the Canadian Institutes of Health Research. He has received research grants and honoraria from HoffmanLaRoche. Laurie Morrison is a co-investigator on the TRANSFER-AMI trial and has received honoraria from Hoffman-LaRoche and unrestricted research grants from Aventis. She is the chair of the Acute Myocardial Infarction/Acute Coronary Syndrome Task Force for ILCOR, the International Liaison Committee on Resuscitation.

Contributors: Warren Cantor was involved with the study conception and design; data acquisition, analysis and interpretation; and the drafting of the article. Fabrice Brunet was involved with the acquisition, analysis and interpretation of the data; Carolyn Ziegler, with data acquisition; and Alex Kiss, with data analysis and interpretation. Laurie Morrison was involved in the conception and design of the study, and the analysis and interpretation of the data. All authors revised the article critically and approved the final version to be published.

\section{REFERENCES}

I. Cantor WJ. Rationale and lexicon of primary angioplasty. In: Tcheng JE, ed. Primary angioplasty in acute myocardial infarction. Totawa, NJ: Humana Press; 2002: I-7.

2. Antman EM, Anbe DT, Armstrong PW, et al; American College of Cardiology; American Heart Association Task Force on Practice Guidelines. ACC/AHA guidelines for the management of patients with ST-elevation myocardial infarction executive summary: a report of the American College of Cardiology/American Heart Association Task Force on Practice Guidelines (Writing Committee to Revise the 1999 Guidelines for the Management of Patients With Acute Myocardial Infarction) [practice guideline]. Circulation 2004;110:588-636. Available: http://circ .ahajournals.org/cgi/content/full/Iro/5/588 or http://circ.ahajournals.org/cgi /reprint/IIo/5/588 (both accessed 2005 Nov 4).

3. International Liaison Committee on Resuscitation. 2005 International consensus on cardiopulmonary resuscitation and emergency cardiovascular care science with treatment recommendations. Circulation 2005;II2(22): in press.

4. de Bono DP. The European Cooperative Study Group trial of intravenous recombinant tissue-type plasminogen activator (rt-PA) and conservative therapy versus rt-PA and immediate coronary angioplasty. J Am Coll Cardiol I988; I2 (Suppl A):20A-3A.

5. Erbel R, Pop T, Diefenbach C, et al. Long-term results of thrombolytic therapy with and without percutaneous transluminal coronary angioplasty. J Am Coll Cardiol I989;I4:276-85.

6. Rogers WJ, Baim DS, Gore JM, et al. Comparison of immediate invasive, delayed invasive, and conservative strategies after tissue-type plasminogen activator: results of the Thrombolysis in Myocardial Infarction (TIMI) Phase II-A trial. Circulation I990;8I:I457-76.

7. Arnold AER, Serruys PW, Rutsch W, et al. Reasons for the lack of benefit of immediate angioplasty during recombinant tissue plasminogen activator therapy for acute myocardial infarction: a regional wall motion analysis. J Am Coll Cardiol I99I;I7:II-2I.

8. Arnold AER, Simoons ML, Van de Werf F, et al. Recombinant tissue-type plasminogen activator and immediate angioplasty in acute myocardial infarction: oneyear follow-up. Circulation ig92;86:III-20.

9. Ellis SG, Lincoff AM, George BS, et al; the Thrombolysis and Angioplasty in Myocardial Infarction (TAMI) Study Group. Randomized evaluation of coronary angioplasty for early TIMI 2 flow after thrombolytic therapy for the treatment of acute myocardial infarction: a new look at an old study. Coron Artery Dis 1994;5:6II-5.

Io. Dudek D, Bartus S, Kuta M, et al. Percutaneous coronary revascularisation preceded by pharmacotherapy in acute myocardial infarction: early results and assessment of reperfusion of microcirculation. Kardiol Pol 2002;56:403-8.

II. Grech ED, Sutton AGC, Campbell PG, et al. Reappraising the role of immediate intervention following thrombolytic recanalization in acute myocardial infarction. Am J Cardiol 2000;86:400-5.

I2. Grollier G, Breut C, Commeau P, et al. Immediate or deferred percutaneous transluminal coronary angioplasty in acute myocardial infarction: results in II 8 cases. Arch Mal Coeur Vaiss i99o;83:159-66.

13. Kimura K, Tsukahara K, Usui T, et al. Low-dose tissue plasminogen activator followed by planned rescue angioplasty reduces time to reperfusion for acute myocardial infarction treated at community hospitals. Jpn Circ J 200I;65:90I-6.

I4. Kurihara H, Matsumoto S, Tamura R, et al. Clinical outcome of percutaneous coronary intervention with antecedent mutant t-PA administration for acute myocardial infarction. Am Heart J 2004; I47:EI4.

I5. McSweyn DJ, Vacek JL, Robuck OW, et al. The use of percutaneous transluminal coronary angioplasty in myocardial infarction. Tex Heart Inst J1991;18:263-8.

I6. Oude Ophuis TJ, Bar FW, Vermeer F, et al. Early referral for intentional rescue PTCA after initiation of thrombolytic therapy in patients admitted to a community hospital because of a large acute myocardial infarction. Am Heart J I999;137:846-53.

I7. Stack RS, O'Connor CM, Mark DB, et al. Coronary perfusion during acute myocardial infarction with a combined therapy of coronary angioplasty and high-dose intravenous streptokinase. Circulation I988;77:15I-6I.

I8. Bednar F, Widimsky P, Krupicka J, et al. Interhospital transport for primary angioplasty improves the long-term outcome of acute myocardial infarction compared with immediate thrombolysis in the nearest hospital (one-year follow-up of the PRAGUE-I study). Can J Cardiol 2003;I9:II33-7.

I9. Califf RM, Topol EJ, Stack RS, et al; TAMI Study Group. Evaluation of combination thrombolytic therapy and timing of cardiac catheterization in acute myocardial infarction: results of thrombolysis and angioplasty in myocardial infarction - phase 5 randomized trial. Circulation I991;83:1543-56.

20. Fernandez-Aviles F, Alonso JJ, Castro-Beiras A, et al. Routine invasive strategy within 24 hours of thrombolysis versus ischemia-guided conservative approach for acute myocardial infarction with ST-segment elevation (GRACIA-I): a randomised controlled trial. Lancet 2004;364:1045-53.

2I. Scheller B, Hennen B, Hammer B, et al. Beneficial effects of immediate stenting after thrombolysis in acute myocardial infarction. J Am Coll Cardiol 2003;42:634-4I.

22. Topol EJ, O'Neill WW, Langburd AB, et al. A randomized, placebo-controlled trial of intravenous recombinant tissue-type plasminogen activator and emergency coronary angioplasty in patients with acute myocardial infarction. Circulation I987;75:420-8.

23. Vermeer F, Oude Ophuis AJ, vd Berg EJ, et al. Prospective randomised comparison between thrombolysis, rescue PTCA, and primary PTCA in patients with extensive myocardial infarction admitted to a hospital without PTCA facilities: a safety and feasibility study. Heart I999;82(4):426-3I.

24. Herrmann HC, Moliterno DJ, Ohman EM, et al. Facilitation of early percutaneous coronary intervention after reteplase with or without abciximab in acute myocardial infarction: results from the SPEED (GUSTO-4 Pilot) Trial. J Am Coll Cardiol 2000;36:I489-96.

25. Schweiger MJ, Cannon CP, Murphy SA, et al. Early coronary intervention following pharmacologic therapy for acute myocardial infarction (the combined TIMI IoBTIMI I4 experience). Am J Cardiol 200I;88:83 I-6.

26. Ross AM, Coyne KS, Reiner JS, et al; the Plasminogen-activator Angioplasty Compatibility Trial (PACT) investigators. A randomized trial comparing primary angioplasty with a strategy of short-acting thrombolysis and immediate planned rescue angioplasty in acute myocardial infarction: the PACT trial. J Am Coll Cardiol 1999; 34:1954-62.

27. Simoons ML, Arnold AE, Betriu A, et al. Thrombolysis with tissue plasminogen activator in acute myocardial infarction: no additional benefit from immediate percutaneous coronary angioplasty. Lancet I988; I:197-203.

28. TIMI Research Group. Immediate vs delayed catheterization and angioplasty following thrombolytic therapy for acute myocardial infarction: TIMI II A results. JAMA I988;260:2849-58. 
29. Topol EJ, Califf RM, George BS, et al. A randomized trial of immediate versus delayed elective angioplasty after intravenous tissue plasminogen activator in acute myocardial infarction. N Engl J Med I987;317:58I-8.

30. Widimsky P, Groch L, Zelizko M, et al; the PRAGUE study group investigators. Multicentre randomized trial comparing transport to primary angioplasty vs immediate thrombolysis vs combined strategy for patients with acute myocardial infarction presenting to a community hospital without a catheterization laboratory: the PRAGUE study. Eur Heart J 2000;2I:823-3I.

3I. O'Neill WW, Weintraub R, Grines CL, et al. A prospective, placebo-controlled, randomized trial of intravenous streptokinase and angioplasty versus lone angioplasty therapy of acute myocardial infarction. Circulation I992;86:1710-7.

32. Jovell AJ, Lau J, Berkey C, et al. Early angiography and angioplasty following thrombolytic therapy of acute myocardial infarction: metaanalysis of the randomized control trials. Online J Curr Clin Trials I993; Doc No 67; PMID: 8306009.

33. Michels KB, Yusuf S. Does PTCA in acute myocardial infarction affect mortality and reinfarction rates? A quantitative overview (meta-analysis) of the randomized clinical trials. Circulation I995;91:476-85.

34. Topol EJ. Coronary angioplasty for acute myocardial infarction. Ann Intern Med I988;109:970-80.

35. Hochman JS, Sleeper LA, Webb JG, et al. Early revascularization in acute myocardial infarction complicated by cardiogenic shock: SHOCK Investigators (Should We Emergently Revascularize Occluded Coronaries for Cardiogenic Shock). $N$ Engl J Med I999;341:625-34.

36. Berger PB, Holmes DR Jr, Stebbins AL, et al. Impact of an aggressive invasive catheterization and revascularization strategy on mortality in patients with cardiogenic shock in the Global Utilization of Streptokinase and Tissue Plasminogen Activator for Occluded Coronary Arteries (GUSTO-I) trial: an observational study. Circulation 1997;96:122-7.

37. Ellis SG, Da Silva ER, Heyndrickx G, et al. Randomized comparison of rescue angioplasty with conservative management of patients with early failure of thrombolysis for acute anterior myocardial infarction. Circulation 1994;90:2280-4.

38. Sutton AG, Campbell PG, Graham R, et al. A randomized trial of rescue angioplasty versus a conservative approach for failed fibrinolysis in ST-segment eleva- tion myocardial infarction: the Middlesbrough Early Revascularization to Limit INfarction (MERLIN) trial. J Am Coll Cardiol 2004;44:287-96.

39. Ellis SG, Armstrong P, Betriu A, et al; the FINESSE Investigators. Facilitated percutaneous coronary intervention versus primary percutaneous coronary intervention: design and rationale of the Facilitated Intervention with Enhanced Reperfusion Speed to Stop Events (FINESSE) trial. Am Heart J 2004;if47(4):er6 or 684.

40. Kastrati A, Mehilli J, Schlotterbeck K, et al. Early administration of reteplase plus abciximab vs abciximab alone in patients with acute myocardial infarction referred for percutaneous coronary intervention: a randomized controlled trial. JAMA 2004; 291:947-54.

4I. Le May MR, Labinaz M, Turek M, et al. Combined Angioplasty and Pharmacological Intervention versus Thrombolytics ALone in Acute Myocardial Infarction (CAPITAL AMI) Study: six-month results [abstract]. Can J Cardiol 2004;20(Suppl D):I5I.

42. Le May MR, Wells GA, Labinaz M, Davies RF, Turek M, Leddy D, et al. Combined Angioplasty and Pharmacological Intervention versus Thrombolytics ALone in Acute Myocardial Infarction (CAPITAL AMI Study). J Am Coll Cardiol 2005;46:4I7-24.

43. Hochman JS, Sleeper LA, White HD, et al. One-year survival following early revascularization for cardiogenic shock. JAMA 2001;285:190-2.

44. Cantor WJ, Choi R, Heffernan M, et al. Feasibility of facilitated PCI for ST-elevation myocardial infarction in Ontario: results of the TRANSFER-AMI pilot study [abstract]. Can J Cardiol 2004;20(Suppl. D):I52.

45. Di Mario C, Bolognese L, Maillard L, et al. Combined Abciximab REteplase Stent Study in acute myocardial infarction (CARESS in AMI). Am Heart J 2004;I48:378-85

46. Gershlick AH, Wilcox R, Hughes S, et al. REscue Angioplasty versus Conservative therapy or repeat Thrombolysis (REACT) trial for failed reperfusion in AMI [abstract]. Eur Heart J 2004;25:2057.

Correspondence to: Dr. Warren J. Cantor, St. Michael's Hospital, Division of Cardiology, 30 Bond St., Toronto ON M5B IW8; fax 41983I-6213; cantorw@smh.toronto.on.ca

\section{Bourse postdoctorale en rédaction du JAMC}

Lancée en I998, la BOURSE POSTDOCTORALE EN RÉDACTION DU JAMC offre aux médecins en début de formation une occasion intéressante de découvrir les rouages internes d'un journal médical de premier plan. Nous invitons les nouveaux diplômés en médecine et les résidents intéressés à acquérir une riche expérience en rédaction, révision et édition médicales à poser leur candidature. Les boursiers participent à tous les aspects de la production du journal, depuis la prise des décisions sur les manuscrits publiés jusqu'à la sollicitation de commentaires et d'articles d'analyse, en passant par la collaboration avec les auteurs. Les boursiers doivent aussi beaucoup écrire et nous les encourageons à créer des numéros thématiques, des séries ou d'autres innovations pour le journal.

Ce poste à plein temps d'une durée d'un an est offert dans les bureaux du JAMC à Ottawa. Le salaire équivaut à la rémunération des résidents en Ontario.

La prochaine série de demandes porte sur le stage de 2006 qui commence le

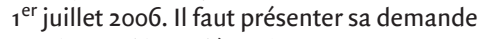
au plus tard le 15 décembre 2005.

Pour obtenir plus de renseignements, veuillez communiquer avec le $D^{r}$ John Hoey, rédacteur en chef, à john.hoey@cma.ca.

\section{CMAJ'JAMC}

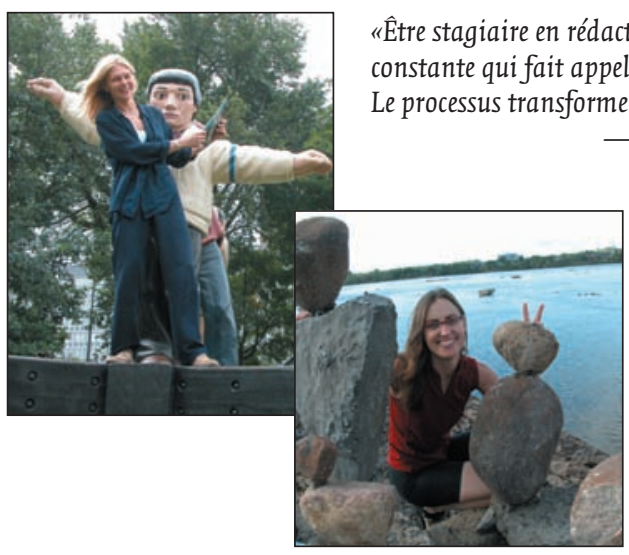

"Je m'intéresse à la santé dans son aspect général - aux moyens d'aborder les problèmes qui touchent la santé de 2000 personnes plutôt que d'une seule. À la façon dont les choses s'imbriquent et s'influencent les unes les autres."

— Sally Murray, stagiaire 2005-2006 